\title{
Role of $\mathrm{Ti}_{3} \mathrm{AlC}_{2} \mathrm{MAX}$ phase on characteristics of in-situ synthesized TiAl intermetallics. Part II: phase evolution
}

\author{
Maryam Akhlaghi ${ }^{a}$, Esmaeil Salahi ${ }^{b, *}$, Seyed Ali Tayebifard ${ }^{\text {a }}$, Gert Schmidt ${ }^{\text {c }}$ \\ ${ }^{a}$ Semiconductors Department, Materials and Energy Research Center (MERC), Karaj, Iran \\ ${ }^{b}$ Ceramics Department, Materials and Energy Research Center (MERC), Karaj, Iran \\ ${ }^{c}$ Faculty of Mechanical, Process and Energy Engineering, TU Bergakademie, Freiberg, Germany
}

\section{A B S T R A C T}

In this research, the $2^{\text {nd }}$ part of a series of papers on the processing and characterization of $\mathrm{TiAl}-\mathrm{Ti}_{3} \mathrm{AlC}_{2}$ composites, the phase evolution during the manufacturing process was investigated by X-ray diffraction (XRD) analysis and Rietveld refinement method. Metallic Ti and $\mathrm{Al}$ powders with different amounts of previously-synthesized $\mathrm{Ti}_{3} \mathrm{AlC}_{2}$ additives $(10,15$, 20, 25 and $30 \mathrm{wt} \%$ ) were ball-milled and densified by spark plasma sintering (SPS) under 40 MPa for 7 min at $900{ }^{\circ} \mathrm{C}$. Before the sintering process, XRD test verified that the powder mixtures contained metallic $\mathrm{Ti}$ and $\mathrm{Al}$ as well as $\mathrm{Ti}_{3} \mathrm{AlC}_{2}$ and $\mathrm{TiC}$ (lateral phase synthesized with $\mathrm{Ti}_{3} \mathrm{AlC}_{2}$ ) phases. In the sintered composites, the in-situ synthesis of $\mathrm{TiAl}$ and $\mathrm{Ti}_{3} \mathrm{Al}$ intermetallics as well as the presence of $\mathrm{Ti}_{3} \mathrm{AlC}_{2}$ and the formation and $\mathrm{Ti}_{2} \mathrm{AlC}$ MAX phases were disclosed. The weight percentage of each phase in the final composition of the samples and the crystallite size of different phases were calculated by the Rietveld refinement method based on the XRD patterns. The size of $\mathrm{Ti}_{3} \mathrm{AlC}_{2}$ crystallites in sintered samples was compared with the crystallite size of synthesized $\mathrm{Ti}_{3} \mathrm{AlC}_{2}$ powder.

(C) 2021 The Authors. Published by Synsint Research Group.

\section{KEYWORDS}

Spark plasma sintering

TiAl

$\mathrm{Ti}_{3} \mathrm{AlC}_{2}$

Phase analysis

Rietveld refinement

Crystallite

\section{Introduction}

TiAl-based composites have gained researcher's attentions because of their unique characteristics including low density, high melting point, as well as excellent corrosion properties, good creep and oxidation resistance [1-6]. However, low-temperature ductility and weak formability of TiAl matrix materials have led to limitation of their application and development [7-10]. Different tricks such as choosing appropriate manufacturing method and addition of reinforcements have been used to dominate such shortcomings [11-13]. Spark plasma sintering is a recently developed method employing for fabrication of various ceramics, polymers, and metals [14-17]. Reproducibility, high sintering rate, and lower consolidation temperatures are the advantages of this method, in comparison to traditional sintering techniques that make easy to attain finer and homogeneous microstructures [18-23].

\begin{abstract}
Some metal additives like $\mathrm{Co}$ and $\mathrm{Fe}$ improved the ductility of TiAl through the occupation of $\mathrm{Al}$ sites by these atoms. In contrast, $\mathrm{Ni}$ addition to TiAl resulted in ductility degradation owing to the formation of NiTi phase at the grain boundaries [24]. Protective surface layer formation of $\mathrm{Al}_{2} \mathrm{O}_{3}$ as a result of adding $\mathrm{Nb}$ or Ta to TiAl matrix improved oxidation resistance at high temperatures [25]. TiAl intermetallic with low wear and high lubricity was fabricated by using $\mathrm{Cu}$-coated graphite. Soft tribo-layer formation and in-situ synthesis of TiC with high inherent hardness are the reasons of such excellent tribological feature [26]. Improvement in the elevated-temperature ductility and room-temperature strength of TiAl material was attributed to the formation of laths due to the addition of Sn [27]. It is reported that Ru has an effective impact on both ductility and strength of TiAl materials through grain refinement mechanism [28].
\end{abstract}

* Corresponding author. E-mail address: e-salahi@merc.ac.ir (E. Salahi)

Received 27 September 2021; Received in revised form 26 December 2021; Accepted 26 December 2021.

Peer review under responsibility of Synsint Research Group. This is an open access article under the CC BY license (https://creativecommons.org/licenses/by/4.0/). https://doi.org/10.53063/synsint.2021.1453 
In addition to metals, using the ceramic compounds is a beneficial way to reinforce the TiAl-based composites. The manufacturing of $\mathrm{Ti}_{5} \mathrm{Si}_{3}$ reinforced TiAl intermetallic by combustion synthesis and hot pressing led to the in-situ formation of $\mathrm{Ti}_{5} \mathrm{Si}_{3}$ that enhanced strength and ductility. Compression strength of hot pressed TiAl materials was significantly improved by nano-sized $\mathrm{TiB}_{2}$ addition [29]. It is also reported that TiAl-based composite with increased density and improved mechanical performance can be fabricated via $\mathrm{TiB}_{2}$ reinforcing, which formed by self-propagating high-temperature synthesis technique [30]. Using high amount of $\mathrm{Y}_{2} \mathrm{O}_{3}$ additive in spark plasma sintered TiAl material resulted in boosted properties via the formation and dispersion of strip-like $\mathrm{YAl}_{2}$ precipitates [31]. Elongation and the ultimate tensile strength of high- $\mathrm{Nb}$ containing TiAl intermetallic increased by adding nano- $\mathrm{Y}_{2} \mathrm{O}_{3}$ via fine-grain strengthening [32].

Given that the density and coefficient of thermal expansion of the TiAl are close to those of MAX phases like $\mathrm{Ti}_{2} \mathrm{AlC}$ with lamellar structure, these materials are used as additives in TiAl intermetallics [33]. $\mathrm{Ti}_{2} \mathrm{AlC}$ reinforced $\mathrm{TiAl}$ were manufactured by powders of $\mathrm{Ti}, \mathrm{Al}$ and carbon elements employing SHS method [34]. Vacuum arc melting process was utilized to synthesize $\mathrm{TiAl}-\mathrm{Ti}_{2} \mathrm{AlC}$ composites using graphite, $\mathrm{Ti}$, and $\mathrm{Al}$ powders [35]. $\mathrm{TiAl}-\mathrm{Ti}_{2} \mathrm{AlC}$ composite materials with layered structure were in-situ synthesized using $\mathrm{Al}$, $\mathrm{Ti}$ and $\mathrm{TiC}$ powders as the raw materials by reactive hot-pressing process. It is reported that TiAl formed by reaction between $\mathrm{Al}$ and Ti below $900^{\circ} \mathrm{C}$; and subsequently, $\mathrm{TiC}$ reacted with formed $\mathrm{TiAl}$ above $900{ }^{\circ} \mathrm{C}$. Increasing the $\mathrm{Ti}_{2} \mathrm{AlC}$ content gradually enhanced the density and hardness [36]. A mechanically alloyed $\mathrm{Ti}-\mathrm{Al}$ powder mixture with CNTs was utilized for in-situ formation of $\mathrm{TiAl}-\mathrm{Ti}_{2} \mathrm{AlC}$ composite with high density and refined microstructure including a continuous interpenetrating network of $\mathrm{Ti}_{2} \mathrm{AlC}$ by spark plasma sintering [37]. $\mathrm{Ti}, \mathrm{Al}$ and $\mathrm{Ti}_{3} \mathrm{AlC}_{2}$ powders as the initial compounds were used to fabricate $\mathrm{TiAl}_{-} \mathrm{Ti}_{3} \mathrm{AlC}_{2}$ sample by spark plasma sintering at temperature of $1000{ }^{\circ} \mathrm{C}$ under $40 \mathrm{MPa}$ for $15 \min [38]$.

In this work, in-situ formed TiAl matrix composites with 10, 15, 20, 25 and $30 \mathrm{wt} \% \mathrm{Ti}_{3} \mathrm{AlC}_{2}$ additives were manufactured by SPS technology under $40 \mathrm{MPa}$ for $7 \mathrm{~min}$ at $900{ }^{\circ} \mathrm{C}$. Phase evolution of $\mathrm{TiAl}_{-} \mathrm{Ti}_{3} \mathrm{AlC}_{2}$ composites during the spark plasma synthesis and sintering is investigated in this paper as the second part of a series of publications. The first part of this series of papers, which has been recently published (Ref. [39]), was dedicated to sintering and densification, and in the next parts, the microstructure, mechanical properties and fractographical characterizations of them will be studied.

\section{Experimental procedure}

Metallic titanium and aluminum powders with equal molar ratios were used as starting materials for in-situ fabrication of TiAl matrix. The technical specifications of the raw materials are reported in Ref. [39]. $\mathrm{Ti}_{3} \mathrm{AlC}_{2}$ MAX phase, which was previously synthesized in our laboratory through the mechanically-activated self-propagating hightemperature synthesis route (MASHS) [40], was used as the reinforcement material with different amounts of 10, 15, 20, 25 and 30 wt $\%$.

Five powder mixtures of $\mathrm{Ti}, \mathrm{Al}$ and $\mathrm{Ti}_{3} \mathrm{AlC}_{2}$ materials were ball-milled for $1 \mathrm{~h}$ at $300 \mathrm{rpm}$, and then filled into the graphite dies with internal diameters of $3 \mathrm{~cm}$, which already had been lined with thin graphite foils. Phase characterization was carried out on the prepared powder mixtures using an X-ray diffractometer (Philips-PW3710: $\lambda_{\mathrm{Cu}^{-}}$ $\left.\mathrm{K}_{\mathrm{a}}=0.15406 \mathrm{~nm}, 40 \mathrm{kV}, 30 \mathrm{~mA}\right)$.

An initial pressure of $\sim 8 \mathrm{MPa}$ and a vacuum of 12-15 Pa were applied to the powder mixtures inside an SPS chamber (model: 20T-10). Then, the densification through spark plasma sintering process was performed at $900{ }^{\circ} \mathrm{C}$ for $7 \mathrm{~min}$ under $40 \mathrm{MPa}$. After grinding and cleaning, the sintered samples were polished with sandpaper from 100 to 5000 mesh and then with diamond paste. Subsequently, phase analyses were also performed on the prepared surface of the samples using an X-ray diffractometer.

\section{Results and discussion}

Fig. 1 shows the X-ray diffraction pattern of the powder mixture, after ball-milling and before sintering, used for the fabrication of TiAl-based composite reinforced with $20 \mathrm{wt} \% \mathrm{Ti}_{3} \mathrm{AlC}_{2}$. As shown in this pattern, the powder mixture contains metallic $\mathrm{Ti}$ and $\mathrm{Al}$ phases as well as $\mathrm{Ti}_{3} \mathrm{AlC}_{2}$ and $\mathrm{TiC}$ compounds. The first three ones, the metallic and MAX phases, were added directly to the powder mixture, but the detection of the $\mathrm{TiC}$ was due to impurities along with the synthesized $\mathrm{Ti}_{3} \mathrm{AlC}_{2}$ phase. Our previous published report and calculations [40], using the Rietveld refinement method, showed that the purity of the $\mathrm{Ti}_{3} \mathrm{AlC}_{2}$ phase synthesized in our laboratory was $85 \mathrm{wt} \%$, and therefore, the presence of about $15 \mathrm{wt} \% \mathrm{TiC}$ in the MAX phase is cognizable.

The results of X-ray diffraction analyses after sintering of the samples at $900{ }^{\circ} \mathrm{C}$ are presented in Fig. 2. The final phases including TiAl, $\mathrm{Ti}_{3} \mathrm{Al}, \mathrm{Ti}_{3} \mathrm{AlC}_{2}$ and $\mathrm{Ti}_{2} \mathrm{AlC}$ appeared in the fabricated composites. Reference JCPDS card numbers of 00-052-0875, 00-029-0095, 00-0520859 and 03-065-0428 were used for identification of $\mathrm{Ti}_{3} \mathrm{AlC}_{2}, \mathrm{Ti}_{2} \mathrm{AlC}$, $\mathrm{Ti}_{3} \mathrm{Al}$ and $\mathrm{TiAl}$ phases, respectively. It seems that the primary metal components (titanium and aluminum) have been completely consumed during the sintering process and converted to the intermetallic compounds of $\mathrm{TiAl}$ and $\mathrm{Ti}_{3} \mathrm{Al}$. It is worth noting that in addition to the initial $\mathrm{Ti}_{3} \mathrm{AlC}_{2}$ MAX phase, a new MAX phase of $\mathrm{Ti}_{2} \mathrm{AlC}$ has also been generated. Meanwhile, the lateral phase of TiC associated with the assynthesized $\mathrm{Ti}_{3} \mathrm{AlC}_{2}$ phase that had been detected in the X-ray diffraction pattern of the as-milled powders (Fig. 1), was not found in

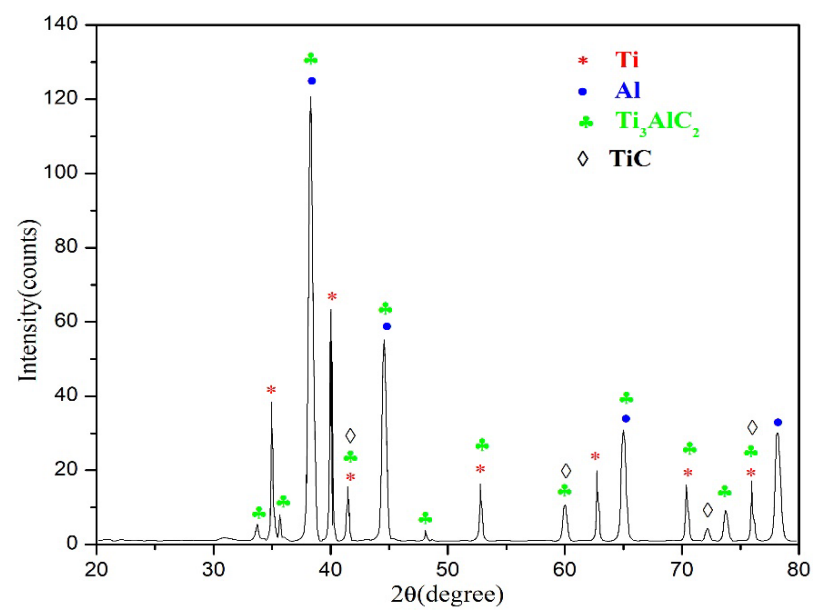

Fig. 1. X-ray diffraction pattern of the milled titanium, aluminum and $\mathrm{Ti}_{3} \mathrm{AlC}_{2}$ powders used for fabrication of the TiAl- $20 \mathrm{wt} \% \mathrm{Ti}_{3} \mathrm{AlC}_{2}$ composite. 

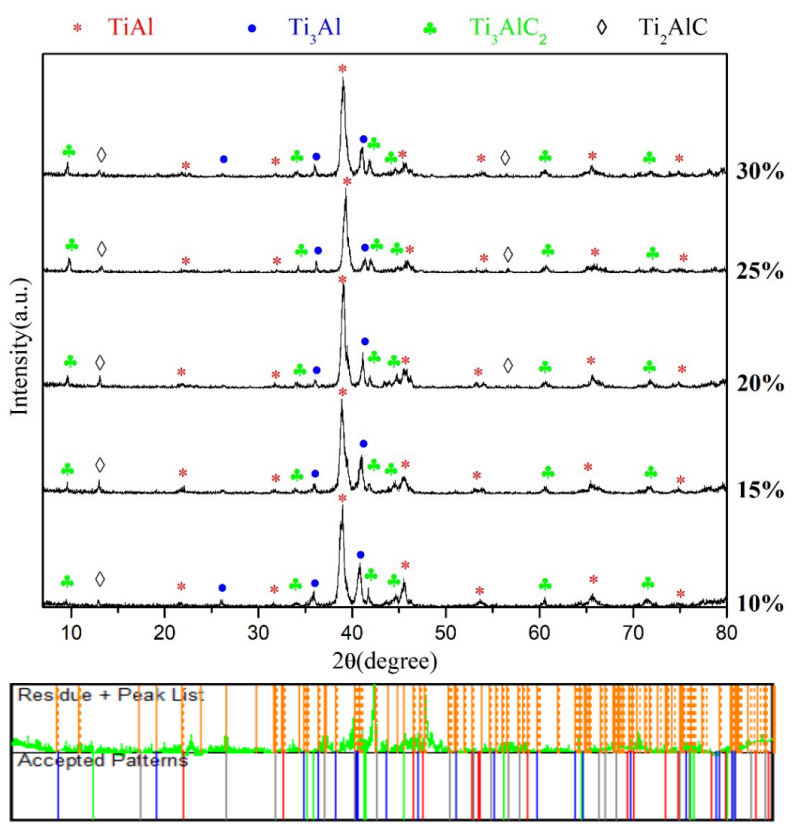

$10 \mathrm{wt} \% \mathrm{Ti}_{3} \mathrm{AlC}_{2}$

Goodness of Fit $=1.73$

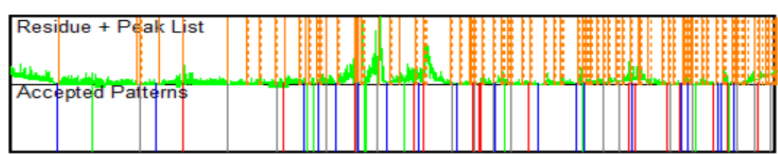

$15 \mathrm{wt} \% \mathrm{Ti}_{3} \mathrm{AlC}_{2}$

Goodness of Fit=1.61

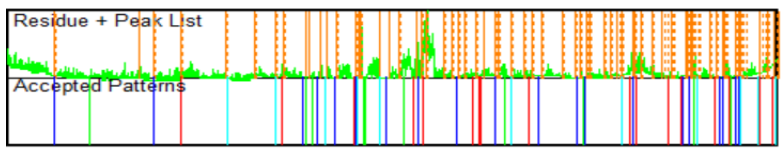

$20 \mathrm{wt} \% \mathrm{Ti}_{3} \mathrm{AlC}_{2}$

Goodness of Fit=1.86

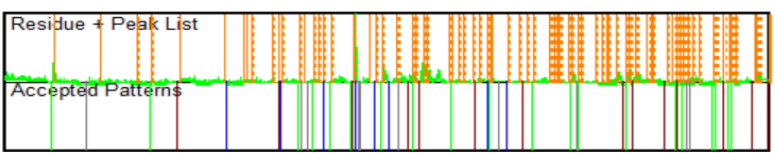

$25 \mathrm{wt} \% \mathrm{Ti}_{3} \mathrm{AlC}_{2}$

Goodness of Fit $=1.48$

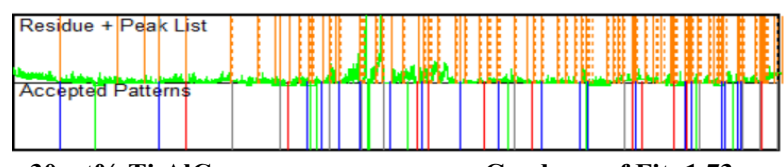

$30 \mathrm{wt} \% \mathrm{Ti}_{3} \mathrm{AlC}_{2}$

Goodness of $\mathrm{Fit}=1.73$

Fig. 2. X-ray diffraction patterns of the as-sintered TiAl-based composites reinforced with different amounts of $\mathrm{Ti}_{3} \mathrm{AlC}_{2}$ additives.

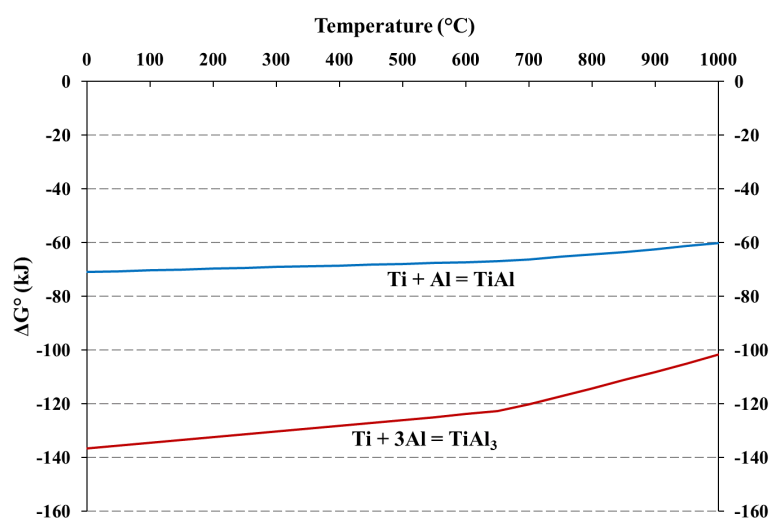

Fig. 3. Gibbs free energy changes of formation of two intermetallics between $\mathrm{Ti}$ and $\mathrm{Al}$ versus temperature.

the X-ray diffraction patterns (Fig. 2) of any of the sintered composite specimens, indicating complete TiC consumption during the manufacturing process.

Several intermetallic compounds can be obtained from the reaction of primary titanium and aluminum metal powders, including $\mathrm{TiAl}, \mathrm{TiAl}_{3}$ and $\mathrm{Ti}_{3} \mathrm{Al}$ in accordance with Eqs. 1-3, respectively. In general, Gibbs free energy changes $\left(\Delta \mathrm{G}^{\circ}\right)$ predict the possibility of a reaction occurring spontaneously, and that reaction occurs when $\Delta G^{\circ}$ is negative. Fig. 3 shows these changes for the formation reactions of $\mathrm{TiAl}$ and $\mathrm{TiAl}_{3}$ intermetallic phases from 0 to $1000{ }^{\circ} \mathrm{C}$ using $\mathrm{HSC}$ Chemistry software. Unfortunately, $\mathrm{Ti}_{3} \mathrm{Al}$ phase data was not available in the database of that software.

$\mathrm{Ti}+\mathrm{Al}=\mathrm{TiAl}$

$\mathrm{Ti}+3 \mathrm{Al}=\mathrm{TiAl}_{3}$

$3 \mathrm{Ti}+\mathrm{Al}=\mathrm{Ti}_{3} \mathrm{Al}$

As shown in Fig. 3, because the Gibbs free energy changes associated with Eq. 2 have negative values than Eq. 1 at all temperatures, the formation of the $\mathrm{TiAl}_{3}$ phase is preferable to the TiAl phase. Ai et al. [41] also showed that the $\mathrm{TiAl}_{3}$ phase is preferentially formed by the reaction of titanium with molten aluminum, which releases a lot of heat. Subsequently, with further increase in temperature, $\mathrm{TiAl}_{3}$ reacts with $\mathrm{Ti}$, and therefore, intermetallic phases of $\mathrm{TiAl}$ and $\mathrm{Ti}_{3} \mathrm{Al}$ appear according to Eq. 4. Finally, part of the formed TiAl reacts with the lateral $\mathrm{TiC}$ phase, present in the previously -synthesized $\mathrm{Ti}_{3} \mathrm{AlC}_{2}$ powder, and the $\mathrm{Ti}_{2} \mathrm{AlC}$ phase is synthesized based on Eq. 5 .

Table 1. Quantitative phase analysis of the as-sintered composites using the Rietveld refinement method.

\begin{tabular}{cccccc}
\hline Sample no. & $\mathbf{T i}_{3} \mathbf{A l C}_{2}$ content in initial mixture (wt\%) & $\mathbf{T i A l}(\mathbf{w t} \%)$ & $\mathbf{T i}_{3} \mathbf{A l}(\mathbf{w t} \%)$ & $\mathbf{T i}_{3} \mathbf{A l C}_{2}(\mathbf{w t} \%)$ & $\mathbf{T i}_{2} \mathbf{A l C}(\mathbf{w t} \%)$ \\
\hline 1 & 10 & 55.4 & 31.7 & 12.9 & - \\
\hline 2 & 15 & 60.2 & 24.3 & 15.5 & 17.5 \\
\hline 3 & 20 & 63.2 & 14.8 & 21.2 & 2.5 \\
\hline 4 & 25 & 62.1 & 17.0 & 24.3 & 3.0 \\
\hline 5 & 30 & 55.7 & & & \\
\hline
\end{tabular}


$\mathrm{TiAl}_{3}+4 \mathrm{Ti}=2 \mathrm{TiAl}+\mathrm{Ti}_{3} \mathrm{Al}$

$\mathrm{TiAl}+\mathrm{TiC}=\mathrm{Ti}_{2} \mathrm{AlC}$

The above analyzes and discussions, which are consistent with the thermodynamic predictions and the results of XRD analysis, indicate that it is possible to fabricate the $\mathrm{TiAl}-\mathrm{Ti}_{3} \mathrm{Al}$-based composites reinforced with $\mathrm{Ti}_{3} \mathrm{AlC}_{2}-\mathrm{Ti}_{2} \mathrm{AlC}$ MAX phases using $\mathrm{Ti}, \mathrm{Al}$ and $\mathrm{Ti}_{3} \mathrm{AlC}_{2}$ as raw materials through SPS technology.

The results of quantitative analyzes, by Rietveld refinement method, to determine the percentage of matrix phases ( $\mathrm{TiAl}$ and $\mathrm{Ti}_{3} \mathrm{Al}$ ) and MAX phase reinforcements $\left(\mathrm{Ti}_{3} \mathrm{AlC}_{2}\right.$ and $\left.\mathrm{Ti}_{2} \mathrm{AlC}\right)$ in the sintered composites are reported in Table 1. The total weight percentages of $\mathrm{Ti}_{3} \mathrm{AlC}_{2}$ and $\mathrm{Ti}_{2} \mathrm{AlC}$ MAX phases in the final composition of the sintered samples are approximately equal to the amounts of $\mathrm{Ti}_{3} \mathrm{AlC}_{2} \mathrm{MAX}$ phase added to the initial powder mixtures. The reason for this equality can bediscussed that the amount of lateral phase of $\mathrm{TiC}(15 \mathrm{wt} \%)$ in synthesized $\mathrm{Ti}_{3} \mathrm{AlC}_{2}$ powder is approximately equal to the amount of $\mathrm{Ti}_{2} \mathrm{AlC}$ MAX phase synthesized during the sintering. The slight differences in the initial and final values can be attributed to the inherent inaccuracy of the X-ray diffraction test, the Rietveld refinement method, and the use of software for calculations. However, the results are valid because such differences are negligible. Since the amounts of MAX phase additive in the first two samples, which contained 10 and $15 \mathrm{wt} \%$ of $\mathrm{Ti}_{3} \mathrm{AlC}_{2}$, were less than the other samples, and therefore, less lateral $\mathrm{TiC}$ phase was added to their initial powder mixtures, the Rietveld analysis failed to estimate the $\mathrm{Ti}_{2} \mathrm{AlC}$ content. Although one of the diffraction peaks of $\mathrm{Ti}_{2} \mathrm{AlC}$ phase is seen in the Xray diffraction patterns of these samples (Fig. 2), but its quantitative identification was not possible for TiAl-(10,15) wt $\% \quad \mathrm{Ti}_{3} \mathrm{AlC}_{2}$ composites.

Table 2 presents the results of the crystallite size calculations of the $\mathrm{TiAl}, \mathrm{Ti}_{3} \mathrm{Al}$ and $\mathrm{Ti}_{3} \mathrm{AlC}_{2}$ phases using the XRD methodology. It is worth noting that the nature of this method is approximate and the measurement errors are inevitable. Due to the small size of crystallites, the title of nanocomposite can be applied to the SPSed samples in this research work. Comparing the size of $\mathrm{Ti}_{3} \mathrm{AlC}_{2}$ crystallites in the sintered samples (39-41 nm; as seen in Table 2) with the size of the synthesized $\mathrm{Ti}_{3} \mathrm{AlC}_{2}$ powder (39 nm; reported in Ref. [40]), a slight increase in crystallite size occurred during the SPS process. Such an observation, i.e. the minimal crystallite growth, can be related to the nature of spark plasma sintering, and the short dwell time applied in this manufacturing process.

Table 2. Determination of size of crystallites using the XRD analysis for the as-sintered composites.

\begin{tabular}{cccc}
\hline Composite & $\begin{array}{c}\text { TiAl } \\
(\mathbf{n m})\end{array}$ & $\begin{array}{c}\mathbf{T i}_{3} \mathbf{A l} \\
(\mathbf{n m})\end{array}$ & $\begin{array}{c}\mathbf{T i}_{3} \mathbf{A l C} \\
(\mathbf{n m})\end{array}$ \\
\hline $\mathrm{TiAl}-10 \mathrm{wt} \% \mathrm{Ti}_{3} \mathrm{AlC}_{2}$ & 14 & 17 & 41 \\
\hline $\mathrm{TiAl}-15 \mathrm{wt} \% \mathrm{Ti}_{3} \mathrm{AlC}_{2}$ & 13 & 17 & 39 \\
\hline $\mathrm{TiAl}-20 \mathrm{wt} \% \mathrm{Ti}_{3} \mathrm{AlC}_{2}$ & 16 & 11 & 39 \\
\hline $\mathrm{TiAl}-25 \mathrm{wt} \% \mathrm{Ti}_{3} \mathrm{AlC}_{2}$ & 12 & 22 & 40 \\
\hline $\mathrm{TiAl}-30 \mathrm{wt} \% \mathrm{Ti}_{3} \mathrm{AlC}_{2}$ & 12 & 22 & 40 \\
\hline
\end{tabular}

\section{Conclusions}

In the $2^{\text {nd }}$ part of a series of papers, dedicated to processing and characterization of $\mathrm{TiAl}-\mathrm{Ti}_{3} \mathrm{AlC}_{2}$ composites, phase evolution during the SPS of ball-milled $\mathrm{Ti}, \mathrm{Al}$ and $\mathrm{Ti}_{3} \mathrm{AlC}_{2}$ powders was studied. After the ball-milling process, in addition to the starting components of $\mathrm{Ti}$, $\mathrm{Al}$ and $\mathrm{Ti}_{3} \mathrm{AlC}_{2}$, the lateral $\mathrm{TiC}$ (synthesized with $\mathrm{Ti}_{3} \mathrm{AlC}_{2}$ ) was also detected by XRD analysis. During the sintering process, TiAl and $\mathrm{Ti}_{3} \mathrm{Al}$ intermetallics and $\mathrm{Ti}_{2} \mathrm{AlC}$ MAX phase were in-situ synthesized and appeared in the final composition along with the initial $\mathrm{Ti}_{3} \mathrm{AlC}_{2} \mathrm{MAX}$ phase. The $\mathrm{TiAl}_{3}$ phase was initially formed by the reaction of $\mathrm{Ti}$ with molten $\mathrm{Al}$. It then reacted with Ti to form TiAl and $\mathrm{Ti}_{3} \mathrm{Al}$. In addition, part of the TiAl reacted with the TiC to synthesize $\mathrm{Ti}_{2} \mathrm{AlC}$. The results of quantitative phase analysis by the Rietveld refinement method on different phases in sintered samples were in good agreement with the phase evolutions happened on the starting components in the powder mixtures. The results of crystallite size calculations, $39-41 \mathrm{~nm}$ for the sintered samples compared to $39 \mathrm{~nm}$ for the synthesized powder, showed that no significant growth in $\mathrm{Ti}_{3} \mathrm{AlC}_{2}$ crystallites occurred during the SPS process.

\section{References}

[1] M.R. Kabir, L. Chernova, M. Bartsch, Numerical investigation of room-temperature deformation behavior of a duplex type $\gamma \mathrm{TiAl}$ alloy using a multi-scale modeling approach, Acta Mater. 58 (2010) 5834 5847. https://doi.org/10.1016/j.actamat.2010.06.058.

[2] Z. Duan, Y. Han, X. Song, H. Chen, Creep behaviour of equiaxed fine-grain $\gamma$-TiAl-based alloy prepared by powder metallurgy, Mater. Sci. Technol. 36 (2020) 1457-1464. https://doi.org/10.1080/02670836.2020.1790098.

[3] H. Huang, H. Ding, X. Xu, R. Chen, J. Guo, H. Fu, Phase transformation and microstructure evolution of a beta-solidified gamma-TiAl alloy, J. Alloys Compd. 860 (2021) 158082. https://oi.org/10.1016/j.jallcom.2020.158082.

[4] H.P. Lim, W.Y.H. Liew, G.J.H. Melvin, Z.-T. Jiang, A Short Review on the Phase Structures, Oxidation Kinetics, and Mechanical Properties of Complex Ti-Al Alloys, Materials (Basel). 14 (2021) 1677. https://doi.org/10.3390/ma14071677.

[5] Z. Trzaska, G. Bonnefont, G. Fantozzi, J.-P. Monchoux, Comparison of densification kinetics of a TiAl powder by spark plasma sintering and hot pressing, Acta Mater. 135 (2017) 1-13. https://doi.org/10.1016/j.actamat.2017.06.004.

[6] Y. Jiang, Y. He, H. Gao, Recent progress in porous intermetallics: Synthesis mechanism, pore structure, and material properties, J. Mater. Sci. Technol. 74 (2021) 89-104. https://doi.org/10.1016/j.jmst.2020.10.007.

[7] C.Y. Teng, N. Zhou, Y. Wang, D.S. Xu, A. Du, Y.H. Wen, R. Yang, Phase-field simulation of twin boundary fractions in fully lamellar TiAl alloys, Acta Mater. 60 (2012) 6372-6381. https://doi.org/10.1016/j.actamat.2012.08.016.

[8] G.H. Cao, A.M. Russell, C.-G. Oertel, W. Skrotzki, Microstructural evolution of TiAl-based alloys deformed by high-pressure torsion, Acta Mater. 98 (2015) 103-112. https://doi.org/10.1016/j.actamat.2015.07.012.

[9] Y. Garip, Investigation of isothermal oxidation performance of TiAl alloys sintered by different processing methods, Intermetallics. 127 (2020) 106985. https://doi.org/10.1016/j.intermet.2020.106985.

[10] J. Shen, L. Hu, L. Zhang, W. Liu, A. Fang, Y. Sun, Synthesis of $\mathrm{TiAl} / \mathrm{Nb}$ composites with concurrently enhanced strength and plasticity by powder metallurgy, Mater. Sci. Eng. A. 795 (2020) 139997. https://doi.org/10.1016/j.msea.2020.139997. 
[11] H.P. Qu, P. Li, S.Q. Zhang, A. Li, H.M. Wang, The effects of heat treatment on the microstructure and mechanical property of laser melting deposition $\gamma$-TiAl intermetallic alloys, Mater. Des. 31 (2010) 2201-2210. https://doi.org/10.1016/j.matdes.2009.10.045.

[12] H. Clemens, A. Bartels, S. Bystrzanowski, H. Chladil, H. Leitner, G. Dehm, R. Gerling, F.P. Schimansky, Grain refinement in $\gamma$-TiAlbased alloys by solid state phase transformations, Intermetallics. 14 (2006) 1380-1385. https://doi.org/10.1016/j.intermet.2005.11.015.

[13] L. Xiang, F. Wang, J. Zhu, X. Wang, Mechanical properties and microstructure of $\mathrm{Al} 2 \mathrm{O} 3 / \mathrm{TiAl}$ in situ composites doped with $\mathrm{Cr} 2 \mathrm{O} 3$, Mater. Sci. Eng. A. 528 (2011) 3337-3341. https://doi.org/10.1016/j.msea.2011.01.006.

[14] M. Mansoor, M. Mansoor, M. Mansoor, Z. Er, F. Çinar Şahin, Abinitio study of paramagnetic defects in $\mathrm{Mn}$ and $\mathrm{Cr}$ doped transparent polycrystalline A12O3 ceramics, Synth. Sinter. 1 (2021) 135-142. https://doi.org/10.53063/synsint.2021.1340.

[15] B. Nayebi, M. Shahedi Asl, M. Akhlaghi, Z. Ahmadi, S.A. Tayebifard, E. Salahi, M. Shokouhimehr, M. Mohammadi, Spark plasma sintering of TiB2-based ceramics with Ti3AlC2, Ceram. Int. 47 (2021) 11929-11934.

https://doi.org/10.1016/j.ceramint.2021.01.033.

[16] M. Shahedi Asl, B. Nayebi, M. Akhlaghi, Z. Ahmadi, S.A. Tayebifard, E. Salahi, M. Shokouhimehr, M. Mohammadi, A novel $\mathrm{ZrB} 2$-based composite manufactured with Ti3AlC2 additive, Ceram. Int. 47 (2021) 817-827. https://doi.org/10.1016/j.ceramint.2020.08.193.

[17] F. Sadegh Moghanlou, M. Vajdi, M. Sakkaki, S. Azizi, Effect of graphite die geometry on energy consumption during spark plasma sintering of zirconium diboride, Synth. Sinter. 1 (2021) 54-61. https://doi.org/10.53063/synsint.2021.117.

[18] M. Saravana Kumar, S. Rashia Begum, M. Vasumathi, C.C. Nguyen, Q. Van Le, Influence of molybdenum content on the microstructure of spark plasma sintered titanium alloys, Synth. Sinter. 1 (2021) 4147. https://doi.org/10.53063/synsint.2021.1114.

[19] N.F. Mogale, W.R. Matizamhuka, Spark Plasma Sintering of Titanium Aluminides: A Progress Review on Processing, StructureProperty Relations, Alloy Development and Challenges, Metals (Basel). 10 (2020) 1080. https://doi.org/10.3390/met10081080.

[20]M. Musi, B. Galy, J.-P. Monchoux, A. Couret, H. Clemens, S. Mayer, In-situ observation of the phase evolution during an electromagneticassisted sintering experiment of an intermetallic $\gamma$-TiAl based alloy, Scr. Mater. 206 (2022) 114233. https://doi.org/10.1016/j.scriptamat.2021.114233.

[21] D. Wimler, J. Lindemann, T. Kremmer, H. Clemens, S. Mayer, Microstructure and mechanical properties of novel TiAl alloys tailored via phase and precipitate morphology, Intermetallics. 138 (2021) 107316. https://doi.org/10.1016/j.intermet.2021.107316.

[22] M. Vajdi, S. Mohammad Bagheri, F. Sadegh Moghanlou, A. Shams Khorrami, Numerical investigation of solar collectors as a potential source for sintering of ZrB2, Synth. Sinter. 1 (2021) 76-84. https://doi.org/10.53063/synsint.2021.128.

[23] M. Abdolahpour Salari, G. Merhan Muğlu, M. Rezaei, M. Saravana Kumar, H. Pulikkalparambil, S. Siengchin, In-situ synthesis of TiN and TiB2 compounds during reactive spark plasma sintering of BNTi composites, Synth. Sinter. 1 (2021) 48-53. https://doi.org/10.53063/synsint.2021.119.

[24] S. Shu, F. Qiu, C. Tong, X. Shan, Q. Jiang, Effects of Fe, Co and Ni elements on the ductility of TiAl alloy, J. Alloys Compd. 617 (2014) 302-305. https://doi.org/10.1016/j.jallcom.2014.07.199.

[25] P.V. Cobbinah, W. Matizamhuka, R. Machaka, M.B. Shongwe, Y. Yamabe-Mitarai, The effect of Ta additions on the oxidation resistance of SPS-produced TiAl alloys, Int. J. Adv. Manuf. Technol. 106 (2020) 3203-3215. https://doi.org/10.1007/s00170-019-04885-7.
[26] L. Wang, A.K. Tieu, Q. Zhu, J. Chen, J. Cheng, J. Yang, B. Kosasih, Achieving the excellent self-lubricity and low wear of TiAl intermetallics through the addition of copper coated graphite, Compos. Part B Eng. 198 (2020) 108223. https://doi.org/10.1016/j.compositesb.2020.108223.

[27] Q. Duan, Q. Luan, J. Liu, L. Peng, Microstructure and mechanical properties of directionally solidified high-Nb containing $\mathrm{Ti}-\mathrm{Al}$ alloys, Mater. Des. 31 (2010) 3499-3503. https://doi.org/10.1016/j.matdes.2010.02.022.

[28] Q. Liu, P. Nash, The effect of Ruthenium addition on the microstructure and mechanical properties of TiAl alloys, Intermetallics. 19 (2011) 1282-1290. https://doi.org/10.1016/j.intermet.2011.04.005.

[29] S. Shu, B. Xing, F. Qiu, S. Jin, Q. Jiang, Comparative study of the compression properties of TiAl matrix composites reinforced with nano-TiB2 and nano-Ti5Si3 particles, Mater. Sci. Eng. A. 560 (2013) 596-600. https://doi.org/10.1016/j.msea.2012.10.001.

[30] C.L. Yeh, S.H. Su, In situ formation of TiAl-TiB2 composite by SHS, J. Alloys Compd. 407 (2006) 150-156. https://doi.org/10.1016/j.jallcom.2005.06.053.

[31] X. Gu, F. Cao, N. Liu, G. Zhang, D. Yang, H. Shen, D. Zhang, H. Song, J. Sun, Microstructural evolution and mechanical properties of a high yttrium containing TiAl based alloy densified by spark plasma sintering, J. Alloys Compd. 819 (2020) 153264. https://doi.org/10.1016/j.jallcom.2019.153264.

[32] Y. Guo, Y. Liang, J. Lin, F. Yang, Effect of Nano-Y2O3 Addition on Microstructure and Tensile Properties of High-Nb TiAl Alloy Prepared by Spark Plasma Sintering, Metals (Basel). 11 (2021) 1048 https://doi.org/10.3390/met11071048.

[33] X.H. Wang, Y.C. Zhou, Layered Machinable and Electrically Conductive Ti2AlC and Ti3AlC2 Ceramics: a Review, J. Mater. Sci. Technol. 26 (2010) 385-416. https://doi.org/10.1016/S10050302(10)60064-3.

[34] C.L. Yeh, Y.G. Shen, Formation of TiAl-Ti2AlC in situ composites by combustion synthesis, Intermetallics. 17 (2009) 169-173. https://doi.org/10.1016/j.intermet.2008.10.014.

[35] X.-J. Song, H.-Z. Cui, N. Hou, N. Wei, Y. Han, J. Tian, Q. Song, Lamellar structure and effect of Ti2AlC on properties of prepared in - situ TiAl matrix composites, Ceram. Int. 42 (2016) 13586-13592. https://doi.org/10.1016/j.ceramint.2016.05.152.

[36] C. Yang, F. Wang, T. Ai, J. Zhu, Microstructure and mechanical properties of in situ $\mathrm{TiAl} / \mathrm{Ti} 2 \mathrm{AlC}$ composites prepared by reactive hot pressing, Ceram. Int. 40 (2014) 8165-8171. https://doi.org/10.1016/j.ceramint.2014.01.012.

[37] F. Yang, F.T. Kong, Y.Y. Chen, S.L. Xiao, Effect of spark plasma sintering temperature on the microstructure and mechanical properties of a Ti2AlC/TiAl composite, J. Alloys Compd. 496 (2010) 462-466. https://doi.org/10.1016/j.jallcom.2010.02.077.

[38] M. Akhlaghi, S.A. Tayebifard, E. Salahi, M. Shahedi Asl, Spark plasma sintering of TiAl-Ti3AlC2 composite, Ceram. Int. 44 (2018) 21759-21764. https://doi.org/10.1016/j.ceramint.2018.08.272.

[39] M. Akhlaghi, E. Salahi, S.A. Tayebifard, G. Schmidt, Role of Ti3AlC2 MAX phase on characteristics of in-situ synthesized TiAl intermetallics. Part I: sintering and densification, Synth. Sinter. 1 (2021) 169-175. https://doi.org/10.53063/synsint.2021.1347.

[40] M. Akhlaghi, S.A. Tayebifard, E. Salahi, M. Shahedi Asl, G. Schmidt, Self-propagating high-temperature synthesis of Ti3AlC2 MAX phase from mechanically-activated $\mathrm{Ti} / \mathrm{Al} /$ graphite powder mixture, Ceram. Int. 44 (2018) 9671-9678. https://doi.org/10.1016/j.ceramint.2018.02.195.

[41] T. Ai, F. Wang, X. Feng, M. Ruan, Microstructural and mechanical properties of dual Ti3AlC2-Ti2AlC reinforced TiAl composites fabricated by reaction hot pressing, Ceram. Int. 40 (2014) 9947-9953. https://doi.org/10.1016/j.ceramint.2014.02.092. 